\title{
Ecocriticism in Arundhati Roy's The God of Small Things
}

\author{
Priyanka Maral \\ Research Scholar, NET qualified, Department of English University of Allahabad
}

\begin{abstract}
Arundhati Roy has described nature in her novel The God of Small Things. She has dealt with nature in present and in the past that is twenty three years earlier in the novel. In my paper I will deal with exploitation of nature much beyond its limits of regeneration. It is so much damaged that nature loses its soothing power. The condition of the river Meenachal, which the life line of Ayemenen, is full of toxic material and the History House which was a symbol of heritage, is converted into a five star hotel. The surroundings have changed but the river Meenachal flows by the side of hotel is thick and toxic. Roy has described how due to modernization animals are getting harmed as she describes in the case of a temple elephant who dies due to electric current. The endangered insects like moth discovered by Pappachi which needs conservation. The lives of people getting mechanized as in the case of Baby Kochamma who enjoyed gardening once but now she has abandoned it due to her interest in watching television. Her garden is in a wretched condition, the exotic breeds of the area are suppressed by another weed patcha. Roy has tried to show how development is taking place at the cost of loss of natural habitat. I will be dealing with these in brief in my paper.
\end{abstract}

Keywords-Animals, History House, Meenachal, Nature

Eco criticism is a critical mode that looks at the representation of nature and landscape in cultural texts, paying particular attention to attitude s towards 'nature' and the rhetoric employed when speaking about it. It aligns itself with ecological activism and social theory with the assumption that the rhetoric of cultural texts reflects and informs material practices towards the environment, while seeking to increase awareness about it and linking itself (and literary texts ) with other ecological sciences and approaches. (Pramod K. Nayar 242)

A basic definition of eco criticism was provided by an early anthology, The Eco criticism Reader which calls it "the study of the relationship between literature and environment "(Cheryll Glotfelty and Harold Fromm ix)

Arundhati Roy won booker prize for her novel The God of Small Things. Her novel is a blend of nature and characters and she has written her novel in unique manner that they complement one another. In her novel she has tried to portray ecological exploitation of nature by human being in the name of progress and modernization. Through her novel she tries to describe exploitation of nature but through the character of Velutha shows us the way for sustainable development.

The river Meenachal is described as

It was warm, the water green like reapplied silk. With fish in it.With the sky and trees in it.

And at night, the broken yellow moon in it.(123)

But when Rahel returns to Ayemenen after twenty three years river "greeted her with a ghastly skull's smile, with holes where teeth had been and a limp hand raised from a hospital bed". (124)

Though it was June and

Raining the river was no more than a swollen drain now. A thin ribbon of thick water that tapped wearily at the mud banks on either side, sequined with occasional silver of a dead fish. It was choked with a succulent weed, whose furred brown roots saved like thin tentacles under water. Bronze winged lily-trotters walked across it. Splay-footed cautious. (124)

The river which is said to evoke fear is now "a slow, slugging green ribbon laws that ferried garbage to the sea now" (124). Estha found that the river "smelled of shit and pesticide brought with World Bank loans. Most of the fish had dried. The ones that survived suffered from fin -rot and had broken out in boils. (13)

The river is polluted by defecation by children living in huts on the other side of the river. The flow of unadulterated factory waste and washing of clothes and pots by women pollutes the river. In summer "the smell of shit lifted off the river and hovered over Ayemenen like a hot" (125) 
In this novel natural habitat is disturbed by increase in population which has grown in size . The growth in population means more pressure on natural resources and their exploitation. The calmness and natural beauty which plants, river and marshes gave twenty three years earlier has been lost.

Its population "has swelled to the size of a little town. Estha now finds the new, freshly baked iced, Gulf money houses built by nurses masons, wire benders and bank clerks who worked hard and unhappily in faraway place. (13)

Urbanization is described "small fish appear in the puddles that fill the PWD potholes on the highways" (1)

The estate of Karri Saipu known as History House is changed into a hotel called Heritage. The locality is described as "God's Own Country" in hotel brochures.

But it is described as

The view from the hotel was beautiful; but here too the water was thick and toxic. They had built a wall to the screen off slum and prevent it from encroaching on Karri Saipu's estate. There was not much they could do about the smell... they knew those clever Hotel people's poverty was merely a matter of getting used to it. (125-126)

Through this novel she has tried to show how in the name of modernization as has led to ecological degradation of animals and plants due greed of money.

Roy has very skillfully described nature in her novel. She has portrayed nature twenty three years before when Rahel returns to Ayemenen she tries to compare exploitation of nature due to industrialization. When she returns and describes Ayemenen turns green during mid June where "boundaries blur as tapioca fences take root and bloom. Brick walls turns moss green. Pepper vines snake up electric poles. Wild creepers burst through laterite banks and spill across the flooded road."'(1)

Roy describes Baby Kochamma discarded her passion of gardening for her new love of watching TV when a dish antenna is installed. Twenty three years ago her craze for gardening led to her to apply for diploma in ornamental gardening. She spent her days in planting that variety of flowering plants and trees which had very little chance to survive in weather condition of Ayemenen. Her garden became so famous that people from Kottayam came to see it. But as the garden is abandoned exotic planted are suppressed by a weed called patcha.

Like a lion -tamer she tamed twisted vines and nurtured bristling cacti, she limited bonsai plants and pampered rare orchids. She waged war on the weather. She tried to grow edelweiss and Chinese guava. (26-27)

But after twenty three years

It has grown knotted and wild, like a circus whose animals had forgotten their tricks. The weed that people cal communist patcha (because it flourished in Kerala like communism) smothers the more exotic plants. (27)

Through these lines Roy has tried to highlight problem of interference in the ecology of an area. When species of a plant that is endemic is introduced in an area, then exotic breeds of that area are suppressed and are in danger of extinction.

Rahel compares abandoned garden, watching toads and snakes with calm atmosphere and her busy life in Washington, where she worked late night, and smoke of vehicles and industries spreading pollution.

Velutha is the god of small things in the novel. He is a man of ecology who makes small things from wood and other materials gained from nature. Roy describes him as making "tiny wind mills, rattle, minute jewels boxes out of dried palm reeds; he could carve perfect boats out of tapioca stems and figurines on cashew nuts." (74)

$\mathrm{He}$ is a man of nature and for him the most trustworthy companion is nature. Here Wordsworth's idea of nature as a companion in his poem "Tintern Abbey" where he tells his sister Dorothy to trust nature because anybody in this world can betray you but nature will never betray you. This idea of Wordsworth applies on Velutha in this novel. When he driven out of his house by his mother, he takes refuge in the lap of nature near the bank of the river. He starts living near the river Meenachal. He catches fish from the river and cooks it in open fire and he sleeps on the bank of the river. He enjoys swimming in the river and when he is convicted in a false case and betrayed by his family and Communist leader Pillai, he seeks refuge near the bank of the river. $\mathrm{He}$ is not able to 
realize how unintentionally his feet move towards the river after the betrayal of Comrade Pillai. His thirteen night physical relationship with Ammu starts and progresses near the bank of the river. Nature is the witness of their relationship. It can be said that the river Meenachal is life line for Velutha.

When Rahel returns from Washington to Ayemenen, she sees river is covered with plastic bags and weedy surface like subtropical flying flowers. Women wash their clothes and pot in the upstream of the river which contains with unadulterated factory effluent.

The novel gives a vivid description of harmful effects of modernization on animals. In the novel a temple elephant dies due fall of high tension electric wire on his body. His death is mourned by the people. Roy has tried to show that electricity has become a part of our life but it is harmful for an animal, when by an accident he comes in contact with it. The description of a puppy that follows Estha when he returns after Twenty three years to Ayemenen and tries to show his intimacy but Estha is indifferent towards him. In the novel indifference of Chacko is also shown when he sees an electrocuted dead elephant. He enquires if the elephant is Kochu Thomban, an elephant of Ayemenen temple when he came to know that he is not he moves on his way back to Ayemenen.

The discovery of an unknown species of moth by Pappachi, who is an Imperial Entomologist at the Pusa Institute. His discovery is due to an accident when a moth falls in his drink. The moth dies and he dries it, to check its species. He gets angry because it is only after his retirement that the moth is described as a new discovery and is named after his junior whom he disliked, now acting Director of the Department of Entomology. Here Roy describes human nature which thinks only of money and glory and not about conservation of an insect which was unknown till now.

Roy has tried to depict nature through trees, river, mountains, animals and insects. The increase in population which has led to intense pressure on natural resources. The loans that are given to developing countries by World Bank for development have resulted in damaging ecology of developing countries due insensitive exploitation of nature. The result of this is developing countries are destroying their biodiversity in name of development. Through her novel she has tried to suggest that there should be sustainable development. Human beings should exploit natural resources but to such an extent that it can regenerate itself for future needs of our coming generations. Roy has tried to create awareness among people towards nature so that we may conserve our ecology and save our future.

\section{Works Cited}

[1]. Cheryll, Glotfelty and Fromm,Harold. The Eco criticism Reader: Landmarks in Literary Ecology.Athens and London: University of Georgia Press, 1996. Print.

[2]. Nayar, Pramod K. Contemporary Literary and Cultural Theory: From Structuralism to Eco Criticism. New Delhi: Pearson, 2010. Print.

[3]. Roy,Arundhati. The God of Small Things. New Delhi: Penguin Books.1997.Print. 